$\begin{array}{ll}\text { Abstracta Iranica } & \begin{array}{l}\text { Abstracta Iranica } \\ \text { Revue bibliographique pour le domaine irano-aryen }\end{array} \\ & \text { Volume } \mathbf{2 7} \text { | } \mathbf{2 0 0 6} \\ \text { Comptes rendus des publications de } \mathbf{2 0 0 4}\end{array}$

\title{
« Esdras 9 ou les contours d'une stratégie ». Transeuphratène, 28 (2004), pp. 41-48.
}

\section{Astrid Nunn}

\section{(2) OpenEdition}

1 Journals

Édition électronique

URL : http://journals.openedition.org/abstractairanica/5678

DOI : 10.4000/abstractairanica.5678

ISSN : 1961-960X

Éditeur :

CNRS (UMR 7528 Mondes iraniens et indiens), Éditions de l'IFRI

\section{Édition imprimée}

Date de publication : 15 mai 2006

ISSN : 0240-8910

\section{Référence électronique}

Astrid Nunn, « «Esdras 9 ou les contours d'une stratégie ». Transeuphratène, 28 (2004), pp. 41-48. », Abstracta Iranica [En ligne], Volume 27 | 2006, document 59, mis en ligne le 02 janvier 2007, consulté le 25 septembre 2020. URL : http://journals.openedition.org/abstractairanica/5678 ; DOI : https:// doi.org/10.4000/abstractairanica.5678

Ce document a été généré automatiquement le 25 septembre 2020.

Tous droits réservés 


\section{« Esdras 9 ou les contours d'une stratégie ». Transeuphratène, 28 (2004), pp. 41-48.}

\section{Astrid Nunn}

Parmi les multiples aspects que l'on peut aborder dans l'étude du livre d'Esdras, l'A. se penche sur la prière d'Esdras au chapitre 9. Cette prière est-elle la preuve de ce qu'Esdras était un homme profondément ancré dans la foi et les traditions d'Israël, d'une piété et d'un zèle exemplaires, ou bien est-elle l'expression d'une stratégie littéraire et théologique? Pour l'A. Esdras 9 appartient à la seconde catégorie. Esdras apparait comme le médiateur entre le peuple d'Israël et son Dieu qui impose et justifie une structure sociale particulière. Sa prière n'est qu'un stratagème.

\section{INDEX}

Thèmes : 3.2.1. Elam

\section{AUTEURS}

\section{ASTRID NUNN}

Université de Munich 